\title{
Assessing the financial implications of quality management system accreditation on small training providers in KwaZulu-Natal
}

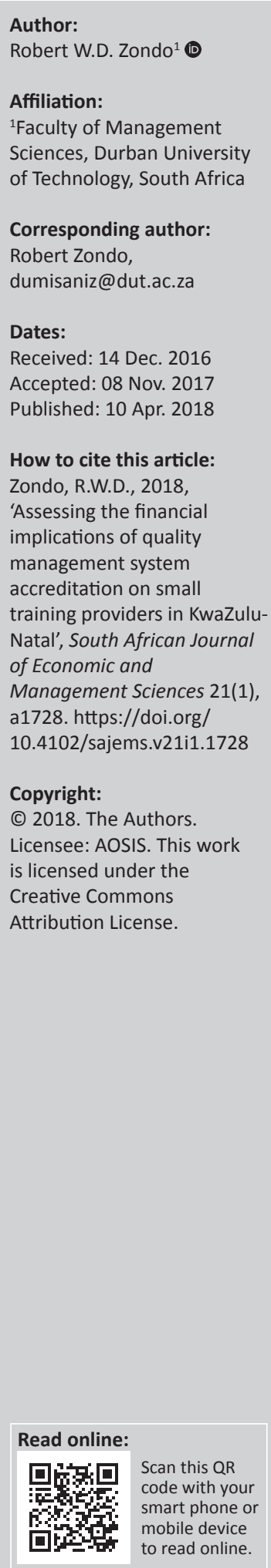

Background: A quality management system (QMS) in education and training is designed in accordance with industry quality models of ISO 9001. Its techniques ensure quality in skills development. However, training providers incur significant costs to obtain QMS accreditation. Therefore, the discourse on the economic effect of QMS accreditation in small training providers is crucial.

Aim: This paper investigates the influence of QMS accreditation on the financial performance of small training providers in KwaZulu-Natal (KZN).

Setting: The South African Qualification Authority (SAQA) is a statutory body, regulated in terms of the National Qualification Framework (NQF) Act No. 67 of 2008 to oversee the development and implementation of the NQF. They are responsible for accrediting 21 sectorbased Education and Training Quality Authorities (ETQAs) for the purpose of monitoring and auditing training achievements in terms of the national standards and qualifications.

Methods: For this study to achieve its objectives, the ETQAs belonging to 12 different Sector Education and Training Authorities (SETAs) provided the sample frame of accredited training providers in KZN. The SETAs are responsible for administering education and training within their industrial sectors. Of the 89 small training providers, 81 participated in the study. Descriptive and correlation analysis were used to test the two objectives. That is, to examine whether the management and marketing practices of QMS accredited small training providers improve their financial performance.

Results: The study indicates that there is no statistical significant relationship between the management and marketing practices of QMS accredited small training providers and their financial performances. This shows that small training providers do not incorporate financial measures during QMS implementation. The accounting departments are not covered in the QMS strategy.

Conclusion: Small training providers should take advantage of QMS accreditation for their business's financial performance. They should incorporate financial indicators during QMS implementation and measure QMS's economic effects on an ongoing basis. The original value of this paper is in its approach in uncovering the strengths and weaknesses of QMS accreditation in the financial performances of accredited small training providers in KZN.

\section{Introduction}

A number of studies in the manufacturing sector were carried out relating to the impact of quality management practices on organisational performance. Results obtained by Gupta (2000) show that ISO 9001 certified companies do differ positively from non-certified ones in technological management, quality management control, causes of poor quality and quality control techniques used. Romano (2000) reports statistically significant improvements after ISO 9001 certification, concerning quality performance in production, the reliability of the production system and external quality performances. The majority of these studies were carried out in the manufacturing sector. Fewer studies focused on the performances of quality management system (QMS) accredited (or certified) small training companies that provide education and training to their defined markets. In education and training, Manyaga (2008) defines QMS accreditation as the quality assurance systems that ensure the provision of set qualifications and educational standards for a particular period of time.

The idea of a QMS in education and training has had little impact, because of the complexity of factors influencing quality in education, such as the attitudes and skills of teachers, abilities and 
motivation of learners, organisational backgrounds, contexts and values, and the existing structures, such as rules, regulations and legislation (Seghezzi 2003). It has been suggested that quality development in education has to focus on incorporating new values, skills and attitudes into professional educators' behaviour in order to have an impact on the teaching and learning (Ehlers 2009). Furthermore, Ehlers (2009) explains that educational quality is the result of a co-production process in an actual learning situation.

Research into the relationship between QMS accreditation in education and training and the performance of training provider organisations is scarce, and the results seem sometimes contradictory. Peters (1999) and Labaree (2000) debate the relevance of QMS to education. Empirical research in this area is necessary; hence, this study aims to bring clarity.

Therefore, this study attempts to find additional insights on the following research questions:

- Is there an influence of management practices of QMS accredited small training providers on financial performance?

- Is there an influence of marketing practices of QMS accredited small training providers on financial performance?

Organisations incur significant costs to obtain quality certification (or accreditation), making it worthwhile to study the process with a view to better understand the pertinent measures for certification success. QMS accreditation requires a focus on performance measures, underscoring that an organisation's management system is a valuable, non-tangible asset. The right business performance measures help focus QMS to achieve desirable and required results in accordance with a QMS certification standard. In one of the comprehensive examinations of the impact of quality on business performance, Sousa and Voss (2002) found that a strong association existed between productivity (both labour and capital) and quality, as well as between profitability and quality. Lapointe and Rivard (2006) found that the relationships between quality and profitability were less established because of the many other variables affecting return on investment (ROI) measures. Sousa and Voss also found strong relationships between productivity improvement and organisational success in such factors as customer satisfaction programmes, product quality improvement, reduction in waste and strategic quality improvement. Relatively little research was conducted into the economic impact of QMS on the accredited small training providers in various sectors of the South African economy. Hence, this paper assesses the financial impact of QMS on the accredited small training providers in KwaZulu-Natal (KZN).

\section{Problem statement: The lack of financial indicators on quality management system}

A financial indicator can be defined as 'something that shows how good a company's financial situation or the situation of a financial market is' (Cambridge Dictionaries 2011). When specifically applied to organisations, this concept is used to refer to those measures that are included in the various accounting and financial reports or to any ratio calculated from them. On the one hand, there are some financial measures, such as the actual total costs and revenues, that can be obtained from the financial statements that every institution issues in accordance with external accounting rules and formats (Leonardo 2014). On the same note, there are indicators, such as profit margins per unit or standard costs and revenues, that are provided by management accounting reports prepared to support internal decisions. However, there are various reasons that discourage organisations from measuring economic effects of QMS implementation. According to Leonardo (2011):

- The measurement of QMS economic effect is not compulsory (that is, it is not required by the National Accounting Standards nor the international standards).

- The shortage and dispersion of QMS monetary data makes the data collection very difficult and the information gathered is usually not precise.

- The accounting department is not covered in the QMS implementation strategy, either due to the dissociation between accounting and other areas or for the reason that QMS is thought to be associated with production or provision of service activities.

Having discussed the problem relating to the lack of incorporating financial indicators during QMS implementation, the next section presents study objectives. These will be followed by the provision of a theoretical framework considered for this study.

\section{Study objectives}

This study assesses the financial implication of QMS on accredited small training providers in KZN. The following are sub-objectives:

- To examine if the management practices of QMS accredited small training providers improve their financial performance.

- To establish if the marketing practices of QMS accredited small training providers improve their financial performance.

\section{Theoretical consideration for this study}

This section presents the impact of QMS accreditation on business financial results, the implications of measuring economic effects of QMS, the motivation for QMS accreditation as well as the relationship between business practices of QMS accredited organisations and financial performance.

\section{The impact of quality management system accreditation on business financial results}

South Africa's quality management relating to its education and training system is based on the keystones of quality of 
commitment, communication and capability (EDUTEL 2011). Commitment is a pledge to follow a policy or get something done. QMS is the sum of the activities and information an organisation uses to enable it to deliver products and services that meet and exceed the needs and expectations of its customers and beneficiaries. Traditionally, business organisations evaluate their performance in terms of quantifiable measures such as profits, turnover (for example, the sales and employee turnover) and financial ratios (Psomas \& Pantouvakis 2015). In recent decades, there has been a growing concern that companies should also address quality-related aspects of performance in their business goals and performance measurements (Zairi \& Alsughayir 2011). These performance aspects and their relevant measurements should be balanced between both financial and operational measures, as well as internal and external measures (Alsmadi, Almani \& Jerisat 2012). The right business performance measures can help QMS implementation to be more efficient and effective (Bell \& Omachonu 2011). QMS implementation reduces the cost of poor quality (Lee, To \& Yu 2009) and increases the organisation's chances of gaining work in the public sector through the creation of better internal management systems and service quality improvement (McAdam \& Canning 2001). As a result, companies need financial indicators that measure the economic impact of QMS accreditation.

Performance measures that demonstrate the value of an organisation's management systems can be difficult to develop, use and interpret (Bell \& Omachonu 2011). Some organisations simply treat the cost of implementing QMS as a business overhead expense often hidden inside various budgets. However, the right business performance measures can help the organisation focus the QMS accreditation process on a more efficient and effective system. The cost and the benefits of implementing a quality management framework can be substantial. Obtaining QMS certification can take up to a year of preparation (Sampaio, Saraiva \& Guimarães 2011). Given its widespread use and economic implications for industry, the QMS framework must be researched to understand which aspects are most beneficial to organisations and to identify the best ways to measure the benefits derived from adopting a management system framework. Various performance measures have been used to quantify the impact of accreditation on organisational performance. Some of these indicators, including the Return on Assets (ROA), sales increase, and market share, have been used most frequently. Return on Equity (ROE) is considered as one of the four key financial ratios used to measure earnings performance. However, equity can be difficult to parse out to divisions of a large corporation and the ROA is commonly used (Kristy 1994, in Sampaio et al. 2011). ROA can be used to characterise the efficiency of an organisation and is often used as an industry standard to indicate what the organisation is capable of, given what it has to work with, and also indicates how much profit the organisation can achieve for each value of assets the company controls (Sun 2000). Hence, an organisation with an effective management system is expected to be more efficient with the use of its resources than the organisations without effective management systems. This research will demonstrate whether a connection exists between QMS accreditation and both the ROI and profit margin of various training providers. It examines whether the management practices of QMS accredited small training providers improve their financial performance. Furthermore, it establishes if the marketing practices of QMS accredited small training providers improve their financial performance.

\section{The implications of measuring economic effects of a quality management system}

Knowing the economic effects of implementing a QMS grants certain advantages to companies because it provides additional information for decision-making. Leonardo (2011) lists some of these advantages as follows:

- It allows organisations to become acquainted with the economic importance of QMS implementation through comparing the actual outcomes achieved with those that would have been reached if this system had not been used. Therefore, it provides evidence of the attainment of the quality management genuine goals, beyond the mere point of receiving a certificate. This information encourages companies to manage quality voluntarily (even if they are not required to do it) and, once implemented, pushes companies to take full advantage of the QMS.

- It enables organisations to learn how much they could increase their profits by implementing quality management, given that this method compares actual economic outcomes to those that would have been gained if QMS had not been implemented with different stringency levels. This information can serve as a decisive factor when making business decisions. For instance, it would allow a company to tell whether it is able to enhance its cost structure in the future by means of reducing quality costs.

- It allows companies to give proper relevance to different kinds of problems or failures that have occurred and allows them to investigate and find causes. A virtue of every common QMS lies in detecting various causes of nonconforming products and in improving opportunities. Additionally, a company can use this measurement tool to make it possible to assign a monetary value to each of these findings on mistakes and errors. The managers then become more challenged if they have to allocate resources in order to solve those problems. The method thus makes it possible to assign or establish a priority to quality problems using an economic consequence criterion.

- It provides information on cost-benefit relationship of each prevention and appraisal action that the company undertakes. Ordinarily, QMS gives information about the effects caused by prevention and appraisal actions but only through non-financial indicators. But, in this proposed method, these non-financial data could become valued in monetary units, which, when compared against its cost, could provide an essential element to decide the implementation of these kinds of actions. 


\section{Motivation for quality management system accreditation}

The motivations for QMS accreditation can be classified according to one of two main categories: internal and external (Sampaio et al. 2011). Internal motivations are related to the goal of achieving organisational improvement, while external motivations are mainly related to promotional and marketing issues, customer pressures, improvement of market share, etc. There is a consensual opinion that ISO 9001 benefits are related to the company certification motivations (that is, when companies become certified based on internal motivations, the derived benefits are fulfilled on a more global dimension). On the other hand, when companies implement ISO 9001 based mostly on external motivations, improvements obtained are then mainly of an external nature (Conca, Llopis \& Tarí 2004; Corbett, MontesSancho \& Kirsch 2005). Companies that sought quality accreditation for 'developmental reasons' have experienced more internal benefits from accreditation. Wiele and Brown (1998) argue that companies driven by internal reasons to seek accreditation have a more positive perception about improvements achieved. The manager who sees accreditation as an opportunity to improve internal processes and systems, rather than simply wanting to get a certificate on the wall, will get broader positive results from QMS accreditation. Gotzamani and Tsiotras (2002) state that companies seeking QMS accreditation mainly based on external motivations will also achieve mostly external benefits, while those that seek accreditation based on true quality improvement will get benefits mainly in terms of internal operations improvement. Conca et al. (2004) explain that companies more concerned with internal reasons are those that:

- obtain higher profits deriving from the implementation of a quality system

- reach a greater practical implementation of quality management principles

- are most likely to progress towards total quality management.

Sampaio et al. (2011) is of the view that companies maximise their benefits if they achieve QMS accreditation based on internal motivations. According to Sousa and Voss (2002), the improvement of product and service quality will influence marketing and business performance and, from there, result in financial performance improvement. Hence, this paper examines the influence of both the management and marketing practices of QMS accredited small training providers on business financial performance.

\section{Relationship between business practices of quality management system accredited organisation and financial performance}

A systematic approach to quality improvement results in two key factors that drive financial performance (George 2002). It generates greater value for customers, builds market share and revenues as well as lowers the costs, increases margins and asset usage. There are a number of studies carried out on areas relating to productivity improvement and organisational success in such factors as customer satisfaction programmes, product quality improvement, reduction in waste and strategic quality improvement. These studies have produced contradictory results on the influence of QMS accreditation on financial improvement. Some authors conclude that there is a positive relationship between QMS accreditation and companies' financial improvements (Dimara et al. 2004) while others do not find evidence to support such a relationship (Heras \& Arana 2006). Singels, Ruël and Van de Water (2001) have also not found a positive relationship between QMS accreditation and the performance of organisations. However, Sampaio et al. (2011) claim that the motivation for seeking accreditation has an influence over the organisation performance. Most organisations seem to pursue QMS accreditation based on external pressures, often resulting in a hollow achievement (Bell \& Omachonu 2011). Only when an organisation is internally motivated for an improvement of its organisational processes will accreditation result in a real significant improvement of its performance. Regarding a better financial performance as indicated by QMS accredited companies, Heras, Casadesús and Ochoa (2001) argue that one must consider the multitude of variables that influence or can influence a company's financial performance. It is important that the characteristics of the samples used by future studies are analysed in greater detail since the higher profitability of the accredited companies may have to do with the sectors under which the accredited firm enjoy greater profitability levels. Heras et al. (2001) add that the higher profitability rates verified among QMS accredited companies may be related to the most profitable companies being those that have a greater propensity to become QMS accredited.

\section{Methodology}

The method of this research will be discussed under the following headings: the target population, brief background of businesses that participated in the study, sample, data collection as well as the measurement and analysis.

\section{Target population}

The population on which this study was conducted comprised 89 small training providers accredited by Sector Education and Training Authorities (SETAs). These providers operate in KZN province. While the focus of the study is on the small training providers, Table 1 illustrates the schedule of size standards in South Africa.

Small training providers who were previously accredited but had had their accreditation withdrawn were excluded from the study. Exclusions also include medium and large training

TABLE 1: Schedule of size standards of small businesses in South Africa.

\begin{tabular}{lccc}
\hline Type of business & $\begin{array}{c}\text { Number of full-time } \\
\text { employees }\end{array}$ & $\begin{array}{c}\text { Turnover (maximum } \\
\text { Rand values) }\end{array}$ & Balance sheet \\
\hline Small & $1-49$ & R13 million & Max. R5 million \\
\hline
\end{tabular}

Source: Olawale, F. \& Garwe, D., 2010, 'Obstacles to the growth of new SMEs in South Africa: Source: Olawale, F. \& Garwe, D., 2010, 'Obstacles to the growth of new SMEs in South Africa:
A principal component analysis approach', African Journal of Business Management 4(1), 729-743 
providers in KZN. Medium-sized businesses are entities that have between 51 and 200 full-time employees while large businesses have more than 200 full-time employees (Olawale \& Garwe 2010).

Some small training providers were accredited by more than one SETA. Providers that had more than $50 \%$ courses under a particular SETA were counted once, to avoid double counting.

\section{Brief background of businesses that participated in the study}

Only businesses registered under the three forms of incorporation (that is, close corporation, private company and non-governmental organisation) participated in the study. The ratio of business participation as per their registration was 6:3:1 with respect to close corporation at $60 \%$, private company at $30 \%$ and non-governmental organisations at $10 \%$.

\section{Sample}

The Education and Training Quality Authorities belonging to 12 different SETAs (that is, Manufacturing, engineering and related services; Energy; Construction; Services; Wholesale and retail; Education, Training and development; Health and welfare; Bank; Transport; Agriculture; Media, information and communication; and Safety and security) provided the sample frame of accredited training providers across South Africa. The respondents were selected based on their business size, their location (i.e. operating within the KZN province), and their ability to access both fax facilities and electronic mails. The study only focused on small training providers whose number of full-time employees ranged between 0 and 50, as in Antonites et al. (2008). The 81 training providers that participated in the study had between 2 and 23 full-time employees. Recruitment of small training providers was undertaken with the aim of ensuring a representative spread of small training providers from the different sectors of the South African economy. A simple random sampling method was used and each small training provider in the KZN population (of small training providers) had an equal likelihood of being selected (Welman, Kruger \& Mitchel 2009). Table 2 shows the percentage of total training providers that participated in the study as per their SETA accreditation.

The highest number of training providers per SETA accreditation that participated in the study was from the Media, information and communication SETA at 27\%, Transport SETA at $13 \%$ and the Agricultural SETA at $10 \%$.

\section{Data collection method}

Data had to be collected from 89 owners of small training providers whose businesses were still in existence. This was achieved by mailing the questionnaires through electronic mail. Similarly, the completed questionnaires were sent back to the researcher via electronic mail or fax. Eighty-one
TABLE 2: Small training providers that participated in the study (as per their Sector Education and Training Authority accreditation).

\begin{tabular}{lc}
\hline SETA represented in the study & $\begin{array}{c}\text { Percentage of small training } \\
\text { providers that participated } \\
\text { in the study }\end{array}$ \\
\hline Manufacturing, engineering and related services SETA & 3 \\
Energy SETA & 7 \\
Construction SETA & 3 \\
Services SETA & 7 \\
Wholesale and retail SETA & 7 \\
Education, training and development SETA & 7 \\
Health and welfare SETA & 7 \\
Bank SETA & 3 \\
Transport SETA & 13 \\
Agriculture SETA & 10 \\
Media, information and communication SETA & 27 \\
Safety and security SETA & 7 \\
\hline
\end{tabular}

SETA, Sector Education and Training Authority.

questionnaires were returned, which represents a $91 \%$ response rate, considered high compared with the norm for survey responses (Baruch \& Holtom 2008). The main reason for this high response rate was due to the invitation letter sent to the small training providers and consistently following up the questionnaires through telephone calls.

\section{Measurement and analysis}

In line with the research framework, the study measured eight variables, using a questionnaire. On the impact of QMS accreditation on financial performance, the study employed a Likert scale, ranging from 1 (strongly agree) to 5 (strongly disagree). Descriptive statistics were used on the impact of QMS accreditation on business financial performance. A Spearman's Rho correlation analysis was applied on both the effect of management practices of QMS accredited small training providers on business financial performance, as well as the effect of marketing practices of QMS accredited training providers on business financial performance.

\section{Effect of management practices of quality management system accredited small training providers on their financial performance}

These variables were measured by four management practice items listed in the questionnaire and were based on the benefits for QMS accreditation to business's financial performance (Feigenbaum 1999; Mak 2011:119; SAQA 2001). These include the management practice of QMS accredited small training providers to: follow specific document procedures, create volumes of paperwork (QMS being a paper-driven process), improve service to learners, and improve productivity.

\section{Effect of marketing practices of quality management system accredited small training providers on their financial performance}

These variables were measured by two marketing items and were based on the benefits for QMS accreditation to business's financial performance (Piskar \& Dolinsek 2006; Quazi \& Jacobs 2004; Sun \& Cheng 2002). The marketing benefits of QMS include demonstration of quality to potential learners and reduction of learner complaints. 
The Statistical Package for the Social Sciences (SPSS) version 23.0 was used to do the data analysis. Descriptive and correlation analysis were used to analyse the three objectives of the study.

\section{Study results}

The following sections assess both the management and marketing practices of QMS accredited small training providers on financial performance (that is, the ROI and profit margins).

\section{Effect of management practices of quality management system accredited small training providers on financial performance}

Spearman's Rho correlation tests were used to find any significant relationship between study variables, which in any two-variable study are dependent or independent of each other, and to find the direction and strength of dependency (Cooper \& Emory 1995). Correlation can reveal the significance of correlation and, if significant, whether it is positive or negative (direction of correlation), as well as the strength of the correlation.

The results of the tests for significant relationships between the variables for management practices of QMS accredited small training providers are shown in Table 3 . The effects on financial performance are discussed in the following two sub-sections. The two financial performance variables are the ROI and profit margins. These two variables were obtained from the organisations that participated in the study and are tested with management practices where QMS:

- ensures businesses follow specific documented procedures

- is a paper-driven process that creates volumes of paperwork

- improves services to learners

- improves productivity.

\section{Management practices of quality management system accredited small training providers and the return on investment}

Table 3 presents results on the management practice variables of QMS accredited training providers with both the ROI and profit margins.

The management practice variables in Table 3 do not statistically have a significant relationship with the ROI. The $p$ values for these variables are more than the standard value of 0.05 . These include QMS as a variable: for ensuring that the business follow specific documented procedures, that creates volumes of paperwork and for improving productivity.

However, the management practice that ensures that QMS improves service to learners and the variable for achieving the ROI have a coefficient $r$-value of 0.373 . This is a directly proportional effect but shows a low correlation between the two variables.
TABLE 3: Effect of management practices on both the return on investment and profit margins.

\begin{tabular}{llcc}
\hline $\begin{array}{l}\text { Management practice } \\
\text { variables }\end{array}$ & Variable & $\begin{array}{c}\text { To achieve the } \\
\text { ROI }\end{array}$ & $\begin{array}{c}\text { To achieve profit } \\
\text { margins }\end{array}$ \\
\hline $\begin{array}{l}\text { QMS helps ensure the } \\
\text { organisation follows specific } \\
\text { documented procedures }\end{array}$ & Correlation & -0.153 & 0.235 \\
Sig. (two-tailed) & 0.437 & 0.220 \\
$\begin{array}{l}\text { QMS is a paper-driven } \\
\text { process that creates }\end{array}$ & $N$ & 78 & 79 \\
volumes of paperwork & Correlation & -0.036 & -0.147 \\
& Sig. (two-tailed) & 0.856 & 0.447 \\
QMS improves service & Correlation & 78 & 79 \\
to learners & Sig. (two-tailed) & 0.373 & 0.146 \\
& $N$ & 78 & 0.449 \\
QMS improves & Correlation & 0.334 & 79 \\
productivity & Sig. (two-tailed) & 0.096 & 0.175 \\
& $N$ & 76 & 0.384 \\
\hline
\end{tabular}

QMS, quality management system; ROI, return on investment; Sig., significance.

Note: Correlation is significant at the 0.05 level (two-tailed).

TABLE 4: Effect of marketing practices on both the return on investment and profit margins.

\begin{tabular}{llcc}
\hline $\begin{array}{l}\text { Marketing practice } \\
\text { variables }\end{array}$ & Variable & To achieve the ROI & $\begin{array}{c}\text { To achieve profit } \\
\text { margins }\end{array}$ \\
\hline $\begin{array}{l}\text { To demonstrate } \\
\text { quality to potential }\end{array}$ & Correlation & -0.077 & -0.272 \\
learners & Sig. (two-tailed) & 0.701 & 0.162 \\
& $N$ & 77 & 78 \\
To reduce learner & Correlation & 0.221 & -0.074 \\
complaints & Sig. (two-tailed) & 0.267 & 0.710 \\
& $N$ & 77 & 78 \\
\hline
\end{tabular}

ROI, return on investment; Sig., significance.

Note: Correlation is significant at the 0.05 level (two-tailed).

\section{Management practices of quality management system accredited small training providers and profit margins}

The management practice variables in Table 3 also do not statistically have a significant relationship with the profit margins. The $p$ values for these variables are more than the standard value of 0.05 . These include QMS as a variable: for ensuring that business follow specific documented procedures, that creates volumes of paperwork, for improving services to learners and for improving productivity.

\section{Effect of marketing practices of quality management system accredited training providers on financial performance}

The Spearman's Rho correlation analysis in Table 4 was also used to test the relationship between the marketing practices of QMS accredited small training providers and financial performance. These analyses are discussed in the following two sub-sections. The two financial performance variables are the ROI and profit margins. These were tested with QMS as a system that:

- demonstrates quality to potential learners

- reduces customer complaints.

Marketing practices of quality management system accredited small training providers and the return on investment

Table 4 presents results on the relationship of marketing practice variables of QMS accredited training providers with both the ROI and profit margins. 
The marketing practice variables in Table 4 do not statistically have a significant relationship with ROI. The $p$ values for these variables are more than the standard value of 0.05 . These include QMS as a variable to demonstrate quality to potential learners and to reduce learner complaints.

\section{Marketing practices of quality management system accredited small training providers and profit margins}

The marketing practice variables in Table 4 also do not statistically have a significant relationship with the profit margins. The $p$ values for these variables are more than the standard value of 0.05 . These include QMS as a variable that demonstrates quality to potential learners and reduces learner complaints.

\section{Discussion}

The main objective of the study was to examine the financial impact of QMS on accredited small training providers in KZN. The study was conducted based on various reasons that discourage organisations from measuring economic effects of QMS implementation (Leonardo 2011). The author indicated that the measurement of QMS economic effect is not required by the National Accounting Standards or the international standards. The accounting department is not covered in the QMS implementation strategy either due to the dissociation between accounting and other areas or for the reason that QMSs are thought to be associated with production. As a result, the influence of QMS accreditation on business' financial performance is not measured. Hence, this study analysed the management and marketing practices of QMS accredited small training providers and their relationship with their financial performance. However, the study revealed that there is no relation between either the management or marketing practices of QMS accredited small training providers and the $\mathrm{ROI}$ and profit margins.

It is crucial that small training providers determine the right business performance measures during QMS implementation in order to be more efficient and effective (Bell \& Omachonu 2011). This reduces the cost of poor quality (Lee et al. 2009) and increases the organisation's chances of gaining work in the public sector through the creation of better internal management systems and service quality improvement (McAdam \& Canning 2001). As a result, companies need financial indicators that measure the financial impact of QMS accreditation.

\section{Implications of results}

During the course of the study, many issues relating to the implications of QMS accreditation were analysed. Consequently, the management and marketing practices of QMS accredited small providers do not show their relationship to financial performance. However, the following recommendations can be made:

- Small training providers should measure the QMS's economic effects. The financial indicators should be incorporated into QMS during its implementation.
- The accounting departments of small training providers should be covered in the QMS strategy.

- Small training providers should measure the impact of QMS accreditation on an ongoing basis.

\section{Limitations of the study}

The usefulness of the findings is constrained by the small sample size. Small training providers who were previously accredited but had had their accreditation withdrawn were excluded from the study. However, the respondents were geographically dispersed within KZN and represented a wide range of industrial sectors.

\section{Conclusion}

The majority of the variables for management and marketing practices of QMS accredited small training providers have no relationship with either the ROI or profit margins. However, the management practice variable that ensures that QMS improves services to learners does have a relationship with the ROI. On the other hand, the improvement of services to learners does not result in an increase in profit margins. Therefore, small training providers should take advantage of QMS accreditation for their business's financial performance. They should incorporate financial indicators during QMS implementation and measure QMS's economic effects on an ongoing basis.

\section{Future research required}

Based on the findings of this study, further research should focus on the market implications of QMS accreditation on small training providers. The studies should explore the market significance of QMS accreditation in South Africa as a whole.

\section{Acknowledgements Competing interests}

The author declares that he has no financial or personal relationships that may have inappropriately influenced him in writing this article.

\section{References}

Alsmadi, M., Almani, A. \& Jerisat, R., 2012, 'A comparative analysis of lean practices and performance in the UK manufacturing and service sector firms', Total Quality Management and Business Excellence 23(4), 381-396. https://doi.org/10.1080/ 14783363.2012.669993

Antonites, A., De Beer, A., Cant, M. \& Jacobs, H., 2008, Entrepreneurship and how to establish your own business, Juta, Cape Town.

Baruch, Y. \& Holtom, B.C., 2008, 'Survey response rate levels and trends in organizational research', Human Relations 61(8), 1139-1160. https://doi.org/ 10.1177/0018726708094863

Bell, M. \& Omachonu, V., 2011, 'Quality system implementation process for business success', International Journal of Quality and Reliability Management 28(1), 723-734. https://doi.org/10.1108/02656711111150814

Cambridge Dictionaries, 2011, Financial indicator, Cambridge University Press, Cambridge, viewed 22 November 2016, from http://dictionary.cambridge.org/ dictionary/business-english/financialindicator

Cooper, D.R. \& Emory, C.W., 1995, Business research methods, 5th edn., McGraw Hill, New York, NY.

Conca, F., Llopis, F. \& Tarí, J., 2004, 'Development of a measure to assess quality management in certified firms', European Journal of Operational Research 156(1), 683-697. https://doi.org/10.1016/S0377-2217(03)00145-0 
Corbett, C., Montes-Sancho, M. \& Kirsch, D., 2005, 'The financial impact of ISO 9000 certification in the US: An empirical analysis', Management Science 51(7), 1046-1059. https://doi.org/10.1287/mnsc.1040.0358

Dimara, E., Skuras, D., Tsekouras, K. \& Goutsos, S., 2004, 'Strategic orientation and financial performance of firms implementing ISO 9000', International Journal of Quality and Reliability Management 21(1), 72-89. https://doi.org/10.1108/ 02656710410511704

EDUTEL, 2011, Skills development facilitator manual, EDUTEL Publishing Johannesburg, South Africa.

Ehlers, U.D., 2009, 'Understanding quality culture', Emerald Group Publishing 17(4), 343-363. https://doi.org/10.1108/09684880910992322

Feigenbaum, A.V., 1999, 'The new quality for the twenty-first century', The TQM Magazine 11(6), 376-383. https://doi.org/10.1108/09544789910287656

George, S., 2002, 'Bull or bear?', Quality Progress April, 32-37.

Gotzamani, K. \& Tsiotras, G., 2002, 'The true motives behind ISO 9000 certification. Their effect on the overall certification benefits and long-term contribution towards TQM', International Journal of Quality \& Reliability Management 19(2), 151-169. https://doi.org/10.1108/02656710210413499

Gupta, A., 2000, 'Quality management practices of ISO vs non-ISO companies: A case of Indian industry', Industrial Management \& Data Systems 100(9), 451-455. https://doi.org/10.1108/02635570010358357

Heras, I. \& Arana, G., 2006, 'The impact of quality management in European companies' performance', European Business Review 18(2), 114-131. https://doi. org/10.1108/09555340610651839

Heras, I., Casadesús, M. \& Ochoa, C., 2001, 'Effects of ISO 9000 certification on companies' profitability: An empirical study', Proceedings of the 6th Internationa Conference on ISO 9000 and TQM, Ayr, 17-19 April.

Kristy, J., 1994, 'Conquering financial ratios: The good, the bad and the who cares', Business Credit 96(2), 14.

Labaree, D., 2000, 'Resisting educational standards', Phi Delta Kappan 82(1), 28-33. https://doi.org/10.1177/003172170008200110

Lapointe, L. \& Rivard, S., 2006, 'Getting physicians to accept new information technology: Insights from case studies', Canadian Medical Association Journal 174(11), 1573-1590. https://doi.org/10.1503/cmaj.050281

Lee, P.K.C., To, W.M. \& Yu, B.T.W., 2009, 'The implementation and performance outcomes of ISO 9000 in service organizations. An empirical taxonomy', International Journal of Quality \& Reliability Management 26(7), 646-662. https://doi.org/10.1108/02656710910975732

Leonardo, A.S.F., 2011, 'Measuring economic effects of quality management systems', The TQM Journal 23(4), 458-474. https://doi.org/10.1108/17542731111139527

Leonardo, A.S.F., 2014, 'Financial indicators in healthcare quality management systems', The TQM Journal 26(4), 312-328. https://doi.org/10.1108/TQM-01-2014-0009

Mak, B.L.M., 2011, 'ISO certificate in the tour operator sector', International Journal of Contemporary Hospitality Management 23(1), 115-130. https://doi.org/ 10.1108/09596111111101706

Manyaga, T., 2008, 'Standards to assure quality in tertiary education: The case of Tanzania', Quality Assurance in Education 16(2), 164-180. https://doi.org/ 10.1108/09684880810868448
McAdam, R. \& Canning, N., 2001, 'ISO in the service sector: Perceptions of small professional firms', Managing Service Quality 11(2), 80-92. https://doi.org/ 10.1108/09604520110387202

Olawale, F. \& Garwe, D., 2010, 'Obstacles to the growth of new SMEs in South Africa: A principal component analysis approach', African Journal of Business Management 4(1), 729-743.

Peters, J., 1999, 'Educational accreditation through ISO 9000', Quality Assurance in Education 7(2), 85-89. https://doi.org/10.1108/09684889910269579

Piskar, F. \& Dolinsek, S., 2006, 'Implementation of the ISO 9001: From QMS to business model', Industrial Management and Data Systems 106(9), 1333-1343. https:// doi.org/10.1108/02635570610712609

Psomas, E. \& Pantouvakis, A., 2015, 'ISO 9001 overall performance dimensions: An exploratory study', The TQM Journal 27(5), 519-531. https://doi.org/10.1108/ TQM-04-2014-0037

Quazi, H. \& Jacobs, R., 2004, 'Impact of ISO 9000 certification on training and development activities', International Journal of Quality and Reliability Management 21(5), 497-517. https://doi.org/10.1108/02656710410536545

Romano, P., 2000, 'ISO 9000: What is its impact on performance?', Quality Management Journal 7(3), 38-56.

SAQA, 2001, QMS for education and training providers, South African Qualification Authority, Brooklyn, Pretoria.

Sampaio, P., Saraiva, P. \& Guimarães, R.A., 2011, 'A classification model for prediction of certification motivations from the contents of ISO 9001 audit reports', Total Quality Management and Business Excellence 21(12), 1279-1298. https://doi.org /10.1080/14783363.2010.529367

Singels, J., Ruël, G. \& Van de Water, H., 2001, 'ISO 9000 series: Certification and performance', International Journal of Quality and Reliability Management 18(1), 62-75. https://doi.org/10.1108/02656710110364477

Seghezzi, H.D., 2003, 'Integriertes Qualitätsmanagement' - Das St. Galler Modell, Hanser Wirtschaft, St. Gallen.

Sousa, R. \& Voss, C., 2002, 'Quality management re-visited: A reflective review and agenda for future research', Journal of Operations Management 20(1), 91-109. https://doi.org/10.1016/S0272-6963(01)00088-2

Sun, H., 2000, 'Total quality management, ISO 900 certification and performance improvement', International Journal of Quality and Reliability Management 17(2), 168-179. https://doi.org/10.1108/02656710010304573

Sun, H. \& Cheng, T.K., 2002, 'Comparing reasons, practices and effects of ISO 9000 certification and TOM implementation in Norwegian SMEs and large firms" International Small Business Journal 20(4), 421-442. https://doi.org/10.1177/ 0266242602204003

Welman, C., Kruger, F. \& Mitchel, B., 2009, Research methodology, Oxford Press, London.

Wiele, T.V.D. \& Brown, A., 1998, 'Venturing down the TQM path for SMEs' International Small Business Journal 16(2), 50-68. https://doi.org/10.1177/ 0266242698162003

Zairi, M. \& Alsughayir, A.A., 2011, 'The adoption of excellence models through cultural and social adaptations: An empirical study of critical success factors and a proposed model', Total Quality Management and Business Excellence 22(6), 641-654. https://doi.org/10.1080/14783363.2011.580654 